\title{
Rapid and Effective Method for Separation of Staphylococcus aureus from Somatic Cells in Mastitis Milk
}

\author{
M. Kubota, ${ }^{\star}$ T. Hayashi,† K. Iwasaki,† H. Ohtsuka,‡ M. Kohiruimaki,‡§ S. Kawamura,‡ \\ K. Sakaguchi, ${ }^{\star}$ and R. Abet $\|^{1}$ \\ *Department of Applied Biological Science, Faculty of Science and Technology, and \\ †Division of Immunobiology, Research Institute for Biological Science, Tokyo University of Science, Noda, Chiba 278-8510, Japan \\ ‡Department of Veterinary Internal Medicine, School of Veterinary Medicine and Animal Sciences, Kitasato University, Towada, \\ Aomori 034-8628, Japan \\ §Kohiruimaki Animal Medical Service, Tohoku, Aomori 039-2683, Japan \\ ||Faculty of Pharmaceutical Sciences, Tokyo University of Science, Noda, Chiba 278-8510, Japan
}

\begin{abstract}
Quantitative PCR can be an effective method for identifying the bacteria causing mastitis. However, PCR detection is hampered by the presence of inflammatory somatic cells. To eliminate this problem, we attempted to establish methods that allow the effective separation of bacterial cells from somatic cells in mastitis milk with amino-silica. Somatic cells and Staphylococcus aureus cells have different sizes, surface structures, and overall electrical charges; therefore, their adsorption and desorption behavior on amino-silica was also different. We found that although amino-silica could efficiently adsorb both somatic cells and Staph. aureus, somatic cells were adsorbed much more strongly than bacterial cells. We identified conditions under which most of the somatic cells adsorbed and only Staph. aureus desorbed from amino-silica upon addition of a desorption solution. We demonstrated that this procedure effectively eliminated somatic cells in heavily contaminated milk samples, which resulted in improved clarity of the PCR band. These results indicate that pretreatment of the samples with amino-silica made the PCR-based strategy for identifying and quantifying disease-causing bacteria applicable for all milk samples.
\end{abstract}

Key words: mastitis, separation, Staphylococcus aureus, somatic cell

\section{INTRODUCTION}

Bovine mastitis is an important disease that is usually caused by bacterial infection. Staphylococcus aureus is one of the major pathogens and is thus of economic significance to dairy farms, because it causes a

Received October 13, 2006.

Accepted May 25, 2007.

${ }^{1}$ Corresponding author: rabe@rs.noda.tus.ac.jp reduction in milk quality and loss of production (Philpot and Nickerson, 2000). Therefore, because of the formation of small abscesses in the udder, early detection and treatment of Staph. aureus mastitis is critically important for the prevention of chronic disease. Early detection of bacteria by PCR assay is one of the easiest and most sensitive methods for identifying the pathogen causing mastitis (Schalm and Noorlander, 1957; Brakstad et al., 1992; Khan et al., 1998; Kim et al., 2001; Phuektes et al., 2001; Riffon et al., 2001; Ercolini et al., 2004). However, a major limitation of the PCRbased method is the presence of inhibitors of DNA polymerase in clinical material (Wiedbrauk et al., 1995; Fredricks and Relman, 1998), which can cause falsenegative PCR results for the detection of target genes. To solve this problem, several applications of the PCR method have been proposed, such as special selection of polymerase and new DNA primer design (Kim et al., 2001; Phuektes et al., 2001; Riffon et al., 2001). Although these modifications have enhanced the sensitivity and specificity of PCR, contamination by inhibitory factors remains problematic.

During the course of bacterial mastitis, active inflammations result in massive migration of inflammatory cells. In addition, the number of endothelial cells also increases sharply. Such a large number of somatic cells often interferes with the PCR assay by making the agarose gel bands smear. As a result, it becomes difficult to identify the infecting bacteria by the PCR method. To solve this problem, we attempted to establish a method of separating bacterial cells from somatic cells in mastitic milk by removing somatic cells from the milk samples.

We have been focusing on silica beads for the separation of microbes by using them as a chromatographic carrier. Silica beads are easily obtainable, stable, and inexpensive compared with other chromatographic carriers such as sepharose. In addition, the surfaces of microbial cells are negatively charged because of the 


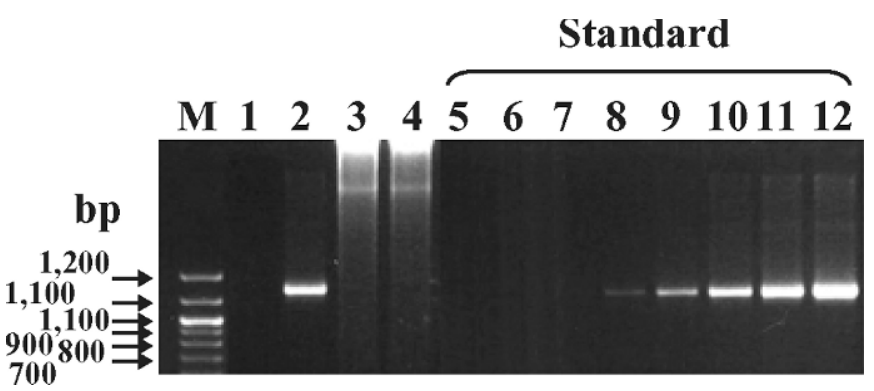

Figure 1. Polymerase chain reaction detection of Staphylococcus aureus. Staphylococcus aureus was detected by agarose gel electrophoresis of the PCR products from various samples. Polymerase chain reaction assays and somatic cell counting were carried out for all samples. Lane 1, PCR amplification from normal commercially available milk (somatic cells, $1 \times 10^{5}$ cells $/ \mathrm{mL}$ ). Lanes 2 to 4 , PCR amplification from mastitis milk contaminated with Staph. aureus (somatic cells in lanes 2,3 , and 4 were $7.5 \times 10^{4}, 6.3 \times 10^{6}$, and $8.3 \times 10^{6}$ cells/ $\mathrm{mL}$, respectively). Lanes 5 to 12 , standard bands, containing $10,10^{2}$, $10^{3}, 10^{4}, 10^{5}, 10^{6}, 10^{7}$ cells $/ \mathrm{mL}$ of Staph. aureus in somatic cell-free solution. $\mathrm{M}=$ marker lane.

presence of carbonyl and phosphate groups (Black, 1996), and amino groups are known to adsorb microbes by electrostatic forces (Kubota et al., 2005). Thus, we assumed that the affinity for amino-silica would be different between somatic cells and bacteria, and that it should be possible to separate these 2 populations by using silica that was modified with amino groups. In this study, we tested the efficiency of this new separation method with a PCR-based method for detecting and identifying Staph. aureus and demonstrated that with this process, we could detect Staph. aureus from heavily contaminated mastitis milk by PCR.

\section{MATERIALS AND METHODS}

\section{Bacterial Strains and Media}

Staphylococcus aureus (ATCC19095) was obtained from the American Type Culture Collection, Global Bioresource Center. Staphylococcus aureus was grown on nutrient broth ( $5 \mathrm{~g}$ of meat extract, $15 \mathrm{~g}$ of peptone, 5 $\mathrm{g}$ of $\mathrm{NaCl}, 5 \mathrm{~g}$ of potassium monohydrogen phosphate, $1,000 \mathrm{~mL}$ of distilled water, $\mathrm{pH} 7$ ) at $30^{\circ} \mathrm{C}$. In the stationary growth phase, cells were harvested by centrifugation $\left(500 \times g, 15 \mathrm{~min}, 4^{\circ} \mathrm{C}\right)$ and washed twice with $10 \mathrm{~m} M$ 3-morpholinopropanesulfonic acid (MOPS, pH 7.0). The cell pellets were collected.

\section{Genomic DNA Extraction}

One milliliter of sample milk (Figures 1 and 2 ) or cell suspension (Figure 3) was centrifuged at $1,500 \times g$ for $15 \mathrm{~min}$ at $4^{\circ} \mathrm{C}$. The pellet was resuspended in $1 \mathrm{~mL}$ of lysis buffer $(0.5 \% N$-laurylsarcosine, $50 \mathrm{~m} M$ Tris-HCl,

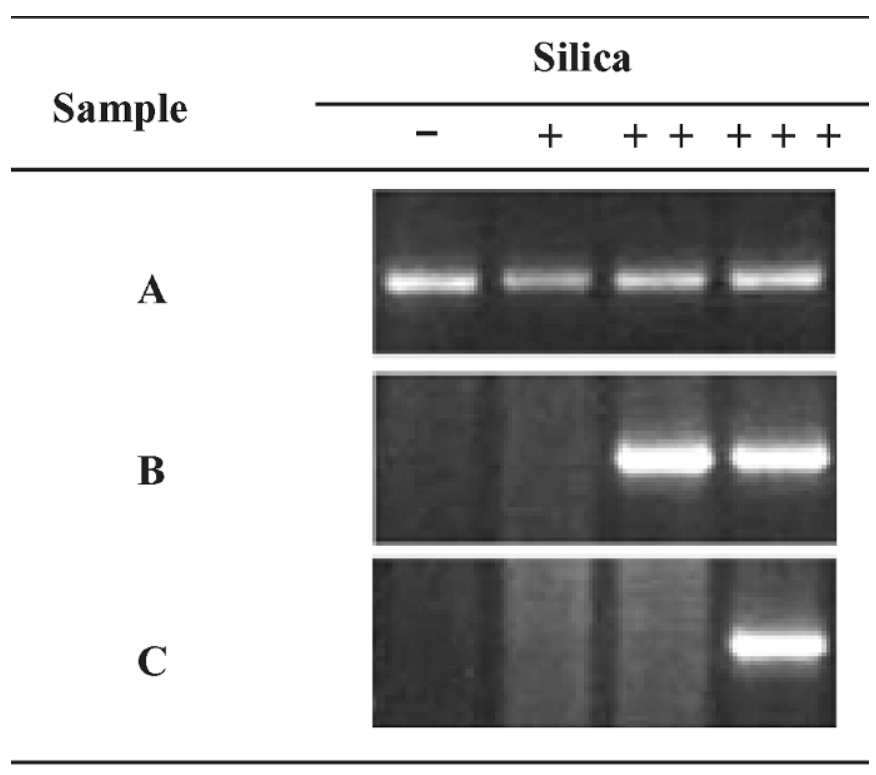

-: 0, +: 12.5, ++:25, +++:50 (mg)

Standard

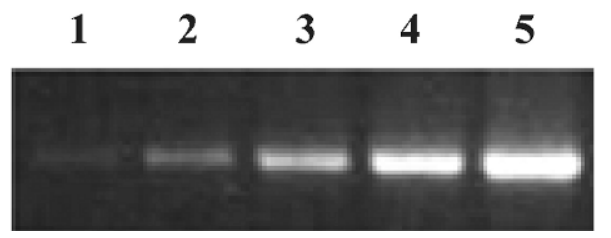

Figure 2. Detection of Staphylococcus aureus from mastitis milk by agarose gel electrophoresis of the PCR products. Three samples of contaminated milk (A, B, and C) were the same samples as used in lanes 2, 3, and 4 of Figure 1, respectively. They were subjected to the separation protocol developed in this study, in which different quantities of amino-silica were used (-, control; +, $12.5 \mathrm{mg} ;++, 25$ $\mathrm{mg} ;+++, 50 \mathrm{mg}$ ). The Staph. aureus-containing fractions were used for PCR assays. The presence of Staph. aureus was confirmed by agarose gel electrophoresis of the PCR products. Standards (lanes 1 to 5) contained controls with increasing numbers of Staph. aureus cells $\left(10^{3}, 10^{4}, 10^{5}, 10^{6}, 10^{7}\right.$ cells $)$.

$25 \mathrm{~m} M$ EDTA) and centrifuged again at $1,500 \times g$ for 15 min at $4^{\circ} \mathrm{C}$. Two hundred microliters of lysostaphin (Wako Pure Chemical Industries, Ltd., Osaka, Japan) was added to the pellet. It was mixed well and incubated for $60 \mathrm{~min}$ at $55^{\circ} \mathrm{C}$. Genomic DNA was extracted with $200 \mu \mathrm{L}$ of phenol and phenol-chloroform. After centrifugation at $15,000 \times g$ for $5 \mathrm{~min}$ at $4^{\circ} \mathrm{C}$, the upper liquid phase was transferred to a new microcentrifuge tube and $1 \mathrm{~mL}$ of ice-cold ethanol was added. After centrifugation at $15,000 \times g$ for $5 \mathrm{~min}$ at $4^{\circ} \mathrm{C}$, the supernatant was removed and dried. Extracted DNA was resuspended in $50 \mu \mathrm{L}$ of TE buffer (10 $\mathrm{m} M$ Tris-HCl, $1 \mathrm{~m} M$ EDTA, $\mathrm{pH}$ 8.0) and incubated for $10 \mathrm{~min}$ at $65^{\circ} \mathrm{C}$. 


\section{A Staph. aureus}

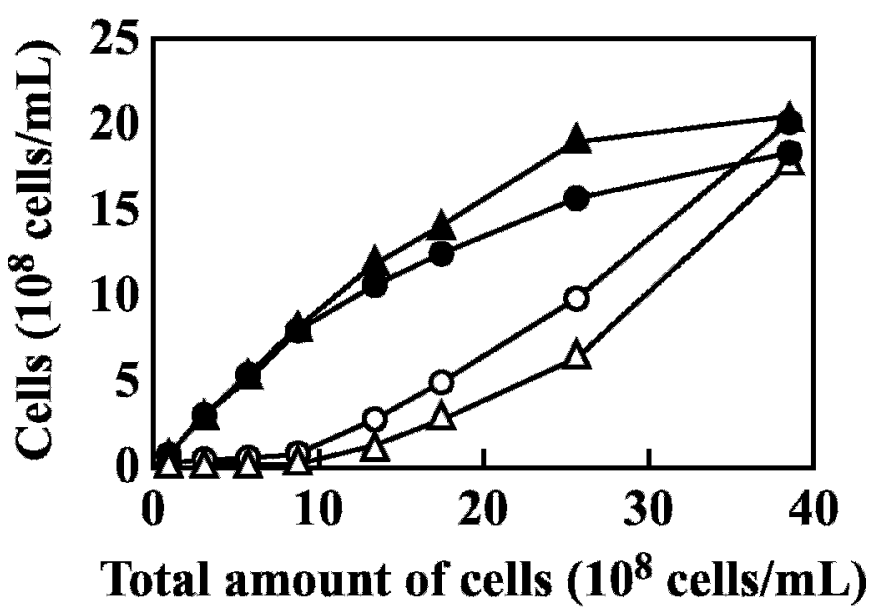

\section{B Leukocytes}

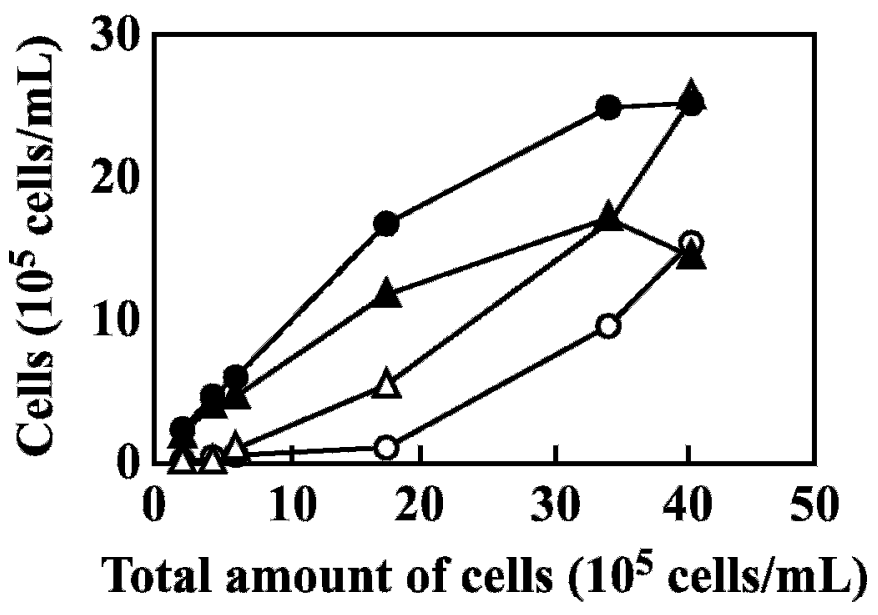

Figure 3. Adsorption of Staphylococcus aureus and leukocytes onto amino-silica and pure silica. Bacterial cells and leukocytes were resuspended to various cell concentrations. Each cell suspension was incubated with $25 \mathrm{mg}$ of silica for $1 \mathrm{~h}$ in $1 \mathrm{~mL}$ of $150 \mathrm{mM} \mathrm{NaCl}, 10$ $\mathrm{m} M$ 3-morpholinopropanesulfonic acid ( $\mathrm{pH}$ 7.0). After incubation, the amount of adsorption was calculated from cell counts. (A) amount of adsorbed Staph. aureus. (B) amount of adsorbed leukocytes. $\bullet$, cells adsorbed onto amino-silica; $\bigcirc$, cells in supernatant from amino-silica; $\triangle$, cells adsorbed onto pure silica; $\boldsymbol{\Delta}$, cells in supernatant from pure silica.

\section{PCR Assay}

The conditions for primary amplification were as follows: an initial denaturation step at $94^{\circ} \mathrm{C}$ for $15 \mathrm{~min}$; 35 cycles of $94^{\circ} \mathrm{C}$ for $45 \mathrm{~s}, 57^{\circ} \mathrm{C}$ for $45 \mathrm{~s}$, and $72^{\circ} \mathrm{C}$ for $45 \mathrm{~s}$; and a final extension step at $72^{\circ} \mathrm{C}$ for $10 \mathrm{~min}$. For multiplex reactions, mixtures consisted of a total volume of $30 \mu \mathrm{L}$ of reaction buffer containing $5 \mu \mathrm{L}$ of bacterial DNA template, $2 \mathrm{~m} M$ deoxynucleoside tri-

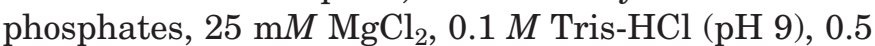
$M \mathrm{KCl}, 1 \%$ Triton X, $10 \mathrm{pmol} / \mathrm{L}$ of forward and reverse primers, and $0.4 \mu \mathrm{L}$ of Taq DNA polymerase (Promega, Madison, WI). The oligonucleotide primers (Invitrogen, Carlsbad, CA) for Staph. aureus genus-specific 23S rRNA were Nuc 1 (5'-ACG GAG TTA CAA AGG ACG AC-3') and Nuc 2 (5'-AGC TCA GCC TTA ACG AGT AC-3'; Nagashima et al., 2000). All PCR products (11 $\mu \mathrm{L})$ were electrophoresed in a Tris-borate-EDTA-2\% agarose gel, visualized by staining with ethidium bromide, and viewed under UV light. A 100-bp DNA ladder (New England Biolabs Inc., Ipswich, MA) was used as a marker.

\section{Purification of Leukocytes}

Healthy Holstein cow blood was obtained from Tokyo Shibaura Zouki (Tokyo, Japan). A 500-mL quantity of blood was centrifuged at $600 \times g$ for $30 \mathrm{~min}$. The buffy coat of blood was obtained after centrifugation and the same quantity of ACK lysing buffer $\left(\mathrm{NH}_{4} \mathrm{Cl}, 8.29 \mathrm{~g} / \mathrm{L}\right.$; $\mathrm{KHCO}_{3}, 1.00 \mathrm{~g} / \mathrm{L}$; EDTA, $0.037 \mathrm{~g} / \mathrm{L} ; \mathrm{pH}$ 7.3) was added for 2 min. A large quantity of PBS buffer was added and the sample was centrifuged at $300 \times g$ for $5 \mathrm{~min}$. After removing the supernatant, cells were washed twice with PBS buffer and once with $10 \mathrm{~m} M$ MOPS and $150 \mathrm{mM} \mathrm{NaCl}(\mathrm{pH} 7)$. The cells were used in the following separation experiments.

The population of cells was treated as described below. Cells were washed with wash buffer (PBS containing $1 \% \mathrm{BSA}$ and $0.05 \% \mathrm{NaN}_{3}$ ) and treated with either anti-GM1 (Veterinary Medical Research and Development Inc., Pullman, WA) or nothing. They were then stained with fluorescent conjugated antibodies [Goat F(ab')2 Anti-Mouse IgG(H+L) FITC Conjugate, Caltag Laboratories Inc., Carlsbad, CA]. A flow cytometer (FACS Calibur, Becton Dickinson Co. Ltd., Sparks, MD) equipped with an argon ion laser was used for measurement of the differential leukocyte count. The isolated cells were nearly all leukocytes (92.86\%).

\section{Adsorption of Bacterial Cells and Leukocytes onto Amino-Silica and Pure Silica}

Bacterial cells and the leukocyte pellet were resuspended in adsorption buffer (150 $\mathrm{mM} \mathrm{NaCl}, 10 \mathrm{~m} M$ MOPS, $\mathrm{pH}$ 7). Cell suspensions were adjusted to various densities and $1 \mathrm{~mL}$ was incubated with $25 \mathrm{mg}$ of aminosilica (NH-DM1020, Fuji Silysia Chemical Ltd., Kasugai, Japan) or pure silica (MB5D, Fuji Silysia Chemical Ltd.) in a microcentrifuge tube on a tube rotator for 60 min at room temperature. After incubation, the silica settled to the bottom of the tube immediately without 
Table 1. Desorption ratio of cells by various solutions

\begin{tabular}{lcc}
\hline & \multicolumn{2}{c}{ Desorption ratio (\%) } \\
\cline { 2 - 3 } Solution & $\begin{array}{c}\text { Staphylococcus } \\
\text { aureus }\end{array}$ & Leukocytes \\
\hline $0.1 M$ NaCl (pH 7) & 14.3 & 0.1 \\
$1 M$ NaCl (pH 7) & 66.5 & 0.7 \\
$1 \%$ pluronic F-68 & 11.8 & 0 \\
$5 \%$ polyethylene glycol 6,000 & 17.5 & 0 \\
0.1 EDTA (pH 8) & 53.8 & 0.8 \\
$0.1 M$ acetic acid (pH 6) & 22.7 & 0.7 \\
$0.1 M$ citric acid (pH 6) & 67.4 & 0.3 \\
$0.1 M$ EDTA, 0.05\% pluronic F-68, 0.1 $M$ NaCl (pH 8) & 83.2 & 1.5 \\
$0.1 M$ citric acid, 0.05\% pluronic F-68, $0.1 M$ NaCl (pH 6) & 89.4 & 0.3 \\
\hline
\end{tabular}

centrifugation. The amount of adsorbing cells was determined by counting the number of cells remaining in the supernatant.

\section{Desorption of Cells from Amino-Silica}

Cell suspensions were prepared [Staph. aureus (optical density $600=0.5), 4.3 \times 10^{8}$ cells $/ \mathrm{mL}$; leukocytes, $7.0 \times 10^{5}$ cells $/ \mathrm{mL}$ ]. Cells in adsorption buffer were adsorbed onto amino-silica for $60 \mathrm{~min}$ at room temperature and the supernatants were removed. After washing with adsorption buffer, cells were incubated with solutions of various compositions (shown in Table 1) for $15 \mathrm{~min}$. The supernatants were removed and cell recovery was examined by spectrometry at $600 \mathrm{~nm}$ (Staph. aureus) or cell counting (leukocytes) of the supernatant.

The following chemical agents were used for desorption experiments: pluronic F-68 (Sigma Chemical Co., St. Louis, MO), polyethylene glycol 6,000 (PEG; Wako Pure Chemical Industries Ltd.), EDTA (Dojindo Ltd., Japan), citric acid, and acetic acid (Wako Pure Chemical Industries Ltd.). The desorption ratio (\%) was calculated as follows:

amount of desorbed cells/amount of adsorbed cells $\times 100$.

\section{Determination of Zeta Potential}

The zeta potential of cells was measured with a Nicomp 380 ZLS instrument (Particle Sizing Systems Co., Santa Barbara, CA) at room temperature. The Nicomp 380 ZLS instrument was equipped with a $20-\mathrm{mW}$ laser diode and photomultiplier tube detector with one optical fiber set at $19.8^{\circ}$. The zeta potential value was calculated from the electrophoretic mobility of the suspensions according to the Helmholtz-Smoluchowski equation (Jan and Chien, 1973; Van Loosdrecht et al., 1987;
Wang et al., 2004; Dittrich and Sibler, 2005). Leukocytes and Staph. aureus were washed with adsorption buffer (150 mM NaCl, $10 \mathrm{~m} M$ MOPS, pH 7), and suspended in adsorption buffer. The suspensions were then transferred to the electrophoresis cell for measurements. The experimental reproducibility was tested 5 times, and the average values are reported here.

\section{Separation of Staph. aureus from an Artificially Mixed Cell Suspension with Amino-Silica}

Cell suspensions of Staph. aureus $\left(8.0 \times 10^{7}\right.$ cells/ $\mathrm{mL})$ and leukocytes $\left(4.0 \times 10^{5}\right.$ cell $\left./ \mathrm{mL}\right)$ were mixed in adsorption buffer. One milliliter of the cell mixture was incubated with $25 \mathrm{mg}$ of amino-silica in adsorption buffer for $60 \mathrm{~min}$ in a microcentrifuge tube. After adsorption, the supernatant (supernatant fraction) was transferred to another tube. Cell-adsorbed amino-silica was washed with $1 \mathrm{~mL}$ of adsorption buffer for $5 \mathrm{~min}$ (wash fraction). The supernatant was removed, and desorption solution (100 $\mathrm{m} M$ citric acid, $0.05 \%$ pluronic F-68, $100 \mathrm{~m} M \mathrm{NaCl}, \mathrm{pH}$ 6) was added. After a 15-min incubation, the supernatant was removed (desorption fraction) and added to the first supernatant tube (recovery fraction).

Cells in each fraction of Staph. aureus and leukocytes were counted, and the percentage of cells present in each fraction was calculated. The initial cell count ratio was assumed to be $100(\%)$. In addition, each fraction was used for DNA extraction and PCR assays.

\section{Separation of Staph. aureus from Milk Samples with Amino-Silica}

Milk samples were collected from cows with clinical or subclinical udder infections within the first $3 \mathrm{wk}$ after delivery. The samples were assessed by the California Mastitis Test (Schalm and Noorlander, 1957) and selected for possible mastitic milk. Staphylococcal mastitis was judged by Staph. aureus-specific PCR assays or 
colony isolation on selective agar plate medium (X-SA medium, Nissui Co., Tokyo, Japan). From these experiments, we selected 2 clinical samples and 1 subclinical sample that were infected with Staph. aureus. Samples were stored at $-30^{\circ} \mathrm{C}$ until further examination.

One milliliter of milk sample was centrifuged at 1,500 $\times g$ for $15 \mathrm{~min}$ at $4^{\circ} \mathrm{C}$ and the supernatant was removed. The pellet was mixed with $12.5,25$, or $50 \mathrm{mg}$ of aminosilica and $1 \mathrm{~mL}$ of adsorption buffer and incubated for 60 min. After adsorption, the supernatant was transferred to a new tube and centrifuged at $1,500 \times g$ for $15 \mathrm{~min}$. After removing the supernatant, the aminosilica was incubated with desorption solution for 15 min. The supernatant was added to the tube containing the pellet from the first adsorption buffer supernatant and centrifuged at $1,500 \times g$ for $15 \mathrm{~min}$. The pellet was used for DNA extraction and PCR assays.

\section{RESULTS}

\section{Detection of Staph. aureus by PCR Assay Hampered by the Presence of Somatic Cells in the Milk}

A semiquantitative PCR assay for the detection of Staph. aureus was established previously (Nagashima et al., 2000). During the course of semiquantitative PCR for the detection of Staph. aureus, we found that PCR products resulting from some milk samples from heavily infected animals were smeared on agarose gels, which made interpretation of the PCR results difficult. As shown in Figure 1, 6 out of 8 samples showed clear bands (lanes 5 to 12) with the Staph. aureus-specific primers, and 2 samples had smeared bands (lanes 3 and 4). We found that the latter 2 samples contained numerous somatic cells and phagocytized bacterial DNA from somatic cells, whereas the others had significantly less. These results suggested that the smeared bands were due to the presence of somatic cells in the milk.

\section{Cell Adsorption Capacity of Amino-Silica and Pure Silica}

Because it seemed that the presence of somatic cells interfered with the PCR assay, we attempted to separate somatic cells from bacteria in the milk samples. To this end, we tried several beads that were expected to have different abilities to absorb bacteria and somatic cells. Among them, silica appeared to be the most suitable for these purposes. Thus, we tested the adsorption of Staph. aureus and leukocytes onto 2-types of silica, amino-silica and pure silica, to determine whether any differences were apparent (Figure 3).
Figure 3A and 3B show the adsorption of Staph. aureus and leukocytes, respectively. We examined adsorption saturation for amino-silica and pure silica in adsorption buffer. Both types of silica adsorbed Staph. aureus equally well (Figure 3A). In contrast, for leukocytes, amino-silica adsorbed better than pure silica (Figure 3B). These experiments also indicated that 25 mg of amino-silica could completely adsorb less than $10^{9}$ cells $/ \mathrm{mL}$ for Staph. aureus and $10^{6}$ cells $/ \mathrm{mL}$ for leukocytes, and that a linear curve was obtained according to the number of cells present in the samples. Thus, in the following experiments, the cell densities used were less than $10^{9}$ cells $/ \mathrm{mL}$ for Staph. aureus and $10^{6}$ cell $\mathrm{s} / \mathrm{mL}$ for leukocytes.

Next, we evaluated several different conditions $(\mathrm{pH}$ 5 to 9,0 to $500 \mathrm{mM} \mathrm{NaCl}$ ) to increase the adsorption efficiency for each type of silica, but we did not observe a notable difference in adsorption (data not shown). Based on these results, we decided to use the original conditions for adsorption of both types of cells onto amino-silica ( $\mathrm{pH} \mathrm{7,} 150 \mathrm{~m} M \mathrm{NaCl}$ ).

\section{Desorption of Cells from Amino-Silica}

Using the previously determined cell numbers and amount of amino-silica, we tested many desorption conditions for Staph. aureus and leukocytes; the results are summarized in Table 1 . First, we tried 0.1 and 1 $M \mathrm{NaCl}$ solutions. Indeed, the $1 M \mathrm{NaCl}$ solution showed good recovery of cells $(66.5 \%)$ compared with the $0.1 \mathrm{M}$ solution (14.3\%), but the recovery of cells with $1 M \mathrm{NaCl}$ was still too low. We then tried using various reagents such as detergents, PEG, EDTA, and organic acids to identify more effective conditions. The use of PEG or pluronic F-68 did not result in good recovery of bacteria. However, the use of EDTA or citric acid was almost as effective in recovering bacteria as was 1 $M \mathrm{NaCl}$. We then tried mixing these solutions with the detergent pluronic F-68. Very high collection rates of 83.2 and $89.4 \%$ were obtained with desorption solutions containing either EDTA or citric acid with pluronic F68 and $100 \mathrm{mM} \mathrm{NaCl}$. The combination of citric acid or EDTA and the detergent pluronic F-68 significantly improved the recovery rate.

In addition, it should be noted that no leukocytes were desorbed from amino-silica under any of the tested conditions (Table 1). In the following experiments, this desorbing solution $[0.1 \mathrm{M} \mathrm{NaCl}$ and $0.1 M$ citric acid, $0.05 \%$ (wt/vol) pluronic F-68, $0.1 \mathrm{M} \mathrm{NaCl}$ ] was used for Staph. aureus recovery.

\section{Separation of Staph. aureus from Artificially Mixed Cell Suspensions}

The characteristic features of adsorption and desorption of pure suspensions of either Staph. aureus or leu- 


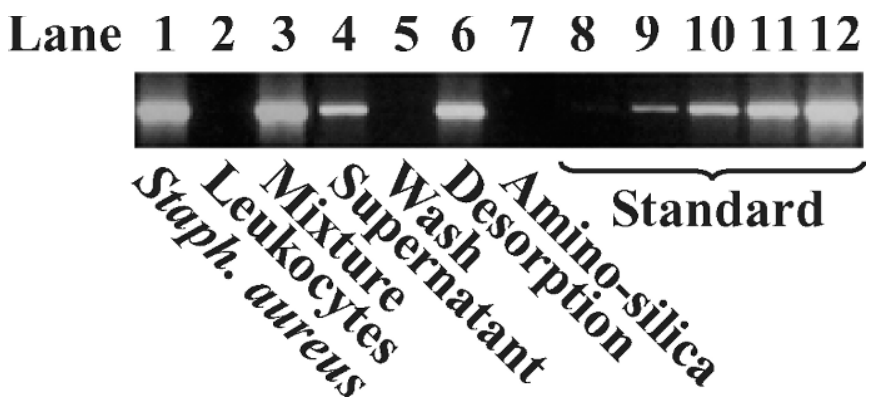

Figure 4. Polymerase chain reaction detection of Staphylococcus aureus in each fraction. Lane 1, amplification from Staph. aureus DNA $\left(8.0 \times 10^{7}\right.$ cells $\left./ \mathrm{mL}\right)$; Lane 2 , amplification from leukocyte DNA $\left(4.0 \times 10^{5}\right.$ cells $\left./ \mathrm{mL}\right)$; Lane 3, product amplified from DNA obtained from the mixture of Staph. aureus $\left(4.0 \times 10^{7}\right.$ cells $\left./ \mathrm{mL}\right)$ and leukocytes $\left(2.0 \times 10^{5}\right.$ cells $\left./ \mathrm{mL}\right)$; Lane 4 , product amplified from DNA from the supernatant of the cell mixture after adsorption onto amino-silica for $1 \mathrm{~h}$; Lane 5, amplification from DNA obtained from the supernatant after washing the silica with adsorption buffer for 5 min; Lane 6, product amplified from DNA obtained from the supernatant of the desorption solution after incubation with cells adsorbed to silica for 15 min; Lane 7, amplification from DNA obtained from amino-silica after incubation with desorption solution for $15 \mathrm{~min}$; Lanes 8-12, standard bands amplified from Staph. aureus $\left(10^{4}, 10^{5}, 10^{6}, 10^{7}, 10^{8}\right.$ cells $/ \mathrm{mL}$ ).

kocytes with amino-silica were determined from these experiments. Next, we conducted experiments to separate Staph. aureus from cell mixtures containing Staph. aureus and leukocytes by using an adsorption buffer.

First, we evaluated the cell recovery ratios by counting cells in each fraction (supernatant, adsorption, and desorption) after adsorption and desorption. After adsorption, leukocytes (99.6\%) and Staph. aureus (43.5\%) were adsorbed onto amino-silica. Staphylococcus aureus $(56.5 \%)$ was then contained in the supernatant fraction. In the desorption fraction, leukocytes $(0.4 \%)$ and Staph. aureus (29.5\%) were gained. Using this method, we collected well-purified Staph. aureus (86.0\%) with very few contaminating leukocytes $(0.8 \%)$.

Next, we tested for the presence of Staph. aureus in each fraction by PCR. As shown in Figure 4, Staph. aureus-specific PCR products were detected in both the supernatant of the cell mixture containing Staph. aureus and leukocytes after adsorption (Figure 4, lane 4 ) and in the desorption solution (Figure 4, lane 6). These results confirmed that we could separate Staph. aureus from the cell mixture without leukocyte contamination.

\section{Detection of Staph. aureus in Mastitis Milk}

Finally, we tested whether these procedures and conditions would eliminate the PCR-based Staph. aureus detection problems in milk samples obtained from farms (Figure 2). We used 3 samples of mastitis milk
(A, B, and C), without a purification step (lanes 2,3 , and 4, respectively, in Figure 1). Although we obtained a clear band from the Staph. aureus-specific PCR for sample A, samples $B$ and $C$ gave a smeared bands on the agarose gel. Next, we applied the new purification procedure for these 3 samples with various quantities of amino-silica. In this experiment, different amounts of amino-silica were added to the samples to completely adsorb all of the somatic cells. Although changing the amount of amino-silica had no effect on sample A, the smearing of the PCR band for sample B was eliminated when more than $25 \mathrm{mg}$ of amino-silica was used. Moreover, in the case of sample $\mathrm{C}$, which showed more strongly smeared bands without treatment, $50 \mathrm{mg}$ of amino-silica was needed to generate clear bands of Staph. aureus PCR product.

To confirm the adsorbing effect of amino-silica on somatic cells, we counted somatic cell numbers in samples before and after adsorption. In particular, $50 \mathrm{mg}$ of amino-silica adsorbed $4.5 \times 10^{6}$ of $6.3 \times 10^{6}$ somatic cells in sample B and $6.0 \times 10^{6}$ of $8.3 \times 10^{6}$ cells in sample C.

\section{DISCUSSION}

Polymerase chain reaction methods have been successfully applied for the detection of microbes in a wide range of sample types (Schalm and Noorlander, 1957; Van Loosdrecht et al., 1987; Brakstad et al., 1992; Khan et al., 1998; Kim et al., 2001; Phuektes et al., 2001; Riffon et al., 2001; Ercolini et al., 2004). However, many polymerase inhibitors have been found in biological specimens such as milk, and somatic cells, particularly leukocytes, present in infected milk appear to be one cause of inhibition. Therefore, methods for the removal of somatic cells and collection of bacterial cells are needed for efficient and sensitive PCR.

Thus, we attempted to establish a new method for the selective separation of Staph. aureus from mastitis milk by using amino-silica before DNA extraction for PCR. We found that although amino-silica could efficiently adsorb both somatic cells and Staph. aureus, somatic cells were much more strongly adsorbed than bacterial cells. We identified specific conditions under which most of the somatic cells adsorbed and only Staph. aureus cells were desorbed from the amino-silica. We tested the efficacy of this new separation method for detection and identification of Staph. aureus by a PCR-based method and demonstrated that after this process, we could dramatically improve detection of Staph. aureus from heavily contaminated mastitis milk by PCR.

We tried many conditions for adsorption and desorption of Staph. aureus and leukocytes to amino-silica. 
Amino-silica adsorbed both leukocytes and Staph. aureus well (Figure 3). To consider the interaction of cells and amino-silica, the cell surface electrical charge was very important. Therefore, we measured the zetapotential of cells to evaluate their electrostatic surface charges. Their zeta-potential values were as follows: leukocytes $-9.29 \pm 6.72$; Staph. aureus cells, $-1.09 \pm$ 3.45 ( $\pm \mathrm{SD})$. This indicates that both Staph. aureus cells and leukocytes are negatively charged. On the other hand, the surface of the amino-silica has many aminogroups; therefore, its surface is positively charged. This information suggests that the attraction force between cells and amino-silica was mainly based on electrostatic interactions. Pure silica could also adsorb both types of cells, but the attraction forces in this case were thought to be mainly due to hydrophobic interactions.

Desorption experiments for Staph. aureus and leukocytes were carried out under various conditions (Table 1). A solution of high ionic strength was thought to detach cells from silica if the adsorption of cells onto silica was caused only by ionic interactions. We found that $1 M \mathrm{NaCl}$ could detach more Staph. aureus cells (66.5\%) than $0.1 \mathrm{M} \mathrm{NaCl}$ (14.3\%), but more efficient recovery was needed. Accordingly, the most appropriate condition to recover Staph. aureus was the combination of citric acid or EDTA and the detergent pluronic F-68. Small molecular weight compounds such as citric acid and EDTA appeared to have stronger affinity for the surface of amino-silica than Staph. aureus cells, so their addition resulted in efficient recovery of Staph. aureus. Moreover, the detergent would weaken the hydrophobic interactions between Staph. aureus and amino-silica. The combination of an organic acid and a detergent was reported to be an effective condition for detaching several bacterial species from silicate material containing amino groups (Kubota et al., 2005). In contrast, no leukocytes were desorbed from amino-silica under any of the tested conditions (Table 1). Furthermore, leukocytes are more negatively charged than Staph. aureus, as mentioned above, and because the cells are larger than bacterial cells, leukocytes would have many more points of contact with the amino-silica compared with Staph. aureus cells. For this reason, we suggest that the attraction between leukocytes and amino-silica was very strong and that the interaction was irreversible in nature.

It should be noted that in the artificial cell mixture, adsorption was different from our expectation, as shown in the results in Figure 3. Leukocytes were well adsorbed even in the mixture, but Staph. aureus cells did not adsorb as strongly (Figure 4). The reason was the difference in affinity between the cells and aminosilica. The leukocytes adsorbed more rapidly onto the amino-silica than did Staph. aureus (data not shown).
Therefore, the adsorption sites for Staph. aureus were thought to be blocked by bound leukocytes. Moreover, this could be explained by the zeta-potential results. For this reason, the electrostatic attraction for aminosilica was thought to be stronger for leukocytes than for Staph. aureus.

Finally, we tried to detect Staph. aureus from naturally occurring mastitis milk samples by our PCR-based method (Figure 2). It was clear that detection of Staph. aureus from samples that were heavily contaminated with somatic cells (Figure 2, samples B and C) was successful, and clear PCR bands were obtained. Moreover, we could find no adverse influence of the pretreatment with amino-silica on detection compared with untreated samples (Figure 2, sample A). This suggests that milk samples in any condition, whether heavily contaminated with somatic cells or not, could be used in this separation system before the PCR assay.

Typically, a concentration of somatic cells of approximately $10^{6}$ cell $/ \mathrm{mL}$ is thought to be the highest contaminating cell level present in mastitis milk, and samples $\mathrm{B}$ and $\mathrm{C}$ in this study had leukocyte concentrations in this range. We could remove almost all of the somatic cells from these samples and succeeded in detecting Staph. aureus by PCR with our method. This suggests that $50 \mathrm{mg}$ of amino-silica was an appropriate amount for use with a real sample of heavily contaminated milk.

The separation system in this study was very effective for samples that may contain polymerase reaction inhibitors (untargeted cells, nucleic acids, or macromolecular compounds such as protein). Moreover, preliminary experiments suggested that other mastitis-causing bacteria, including Escherichia coli, Streptococcus dysgalactiae, Streptococcus agalactiae, and Streptococcus uberis, could also be selectively obtained by this method (data not shown).

In conclusion, this cell separation system was easy, rapid, and inexpensive, and used readily available amino-silica as the primary reagent for selective cell separation. We expect that in the future, the technology developed in this study could be applicable for identifying other bacterial contaminants in the food and dairy industries as well as in the medical field.

\section{REFERENCES}

Black, J. G. 1996. Microbiology Principles and Applications. 3rd ed. Prentice-Hall, Upper Saddle River, NJ.

Brakstad, O. G., K. Aasbakk, and J. A. Maeland. 1992. Detection of Staphylococcus aureus by polymerase chain reaction amplification of the Nuc gene. J. Clin. Microbiol. 30:1654-1660.

Dittrich, M., and S. Sibler. 2005. Cell surface groups of two picocyanobacteria strains studied by zeta potential investigations, potentiometric titration, and infrared spectroscopy. J. Colloid Interface Sci. 286:487-495.

Ercolini, D., G. Blaiotta, V. Fusco, and S. Coppola. 2004. PCR-based detection of enterotoxigenic Staphylococcus aureus in the early 
stages of raw milk cheese making. J. Appl. Microbiol. 96:10901096.

Fredricks, D. N., and D. A. Relman. 1998. Improved amplification of microbial DNA from blood cultures by removal of the PCR inhibitor sodium polyanetholesulfonate. J. Clin. Microbiol. 36:28102816.

Jan, K.-M., and S. Chien. 1973. Role of surface electric charge in red blood cell interactions. J. Gen. Physiol. 6:638-654.

Khan, M. A., C. H. Kim, I. Kakoma, E. Morin, R. D. Hansen, W. L. Hurley, D. N. Tripathy, and B. K. Beak. 1998. Detection of Staphylococcus aureus in milk by use of polymerase chain reaction analysis. Am. J. Vet. Res. 59:807-813.

Kim, C. H., M. Khan, D. E. Morin, W. L. Hurley, D. N. Tripathy, M. Jr. Kehrli, A. O. Oluoch, and I. Kakoma. 2001. Optimization of the PCR for detection of Staphylococcus aureus Nuc gene in bovine milk. J. Dairy Sci. 84:74-83.

Kubota, M., M. Matsui, H. Chiku, N. Kasashima, M. Shimojoh, and K. Sakaguchi. 2005. Cell adsorption and selective desorption for separation of microbial cells by using chitosan-immobilized silica. Appl. Environ. Microbiol. 71:8895-8902.

Nagashima, K., T. Shimizu, K. Takeshi, M. Kawakami, D. Yasokawa, R. Nakagawa, and Y. Okumura. 2000. A simple and sensitive polymerase chain reaction method for detection of food-related bacteria. Food Sci. Technol. Res. 6:115-118.
Philpot, W. N., and S. C. Nickerson. 2000. Winning the Fight Against Mastitis. Westfalia-Surge Inc., Naperville, IL.

Phuektes, P., P. D. Mansell, and G. F. Browning. 2001. Multiplex polymerase chain reaction assay for simultaneous detection of Staphylococcus aureus and streptococcal causes of bovine mastitis. J. Dairy Sci. 84:1140-1148.

Riffon, R., K. Sayasith, H. Khalil, P. Dubreuil, M. Drolet, and J. Lagace. 2001. Development of a rapid and sensitive test for identification of major pathogens in bovine mastitis by PCR. J. Clin. Microbiol. 39:2584-2589.

Schalm, O. W., and D. O. Noorlander. 1957. Experiments and observations leading to the development of the California Mastitis Test. J. Am. Vet. Med. Assoc. 130:199-204.

Van Loosdrecht, M. C., J. Lyklema, W. Norde, G. Schraa, and A. J. Zehnder. 1987. Electrophoretic mobility and hydrophobicity as a measured to predict the initial steps of bacterial adhesion. Appl. Environ. Microbiol. 53:1898-1901.

Wang, J., N. Huang, P. Yang, Y. X. Leng, H. Sun, Z. Y. Liu, and P. K. Chu. 2004. The effects of amorphous carbon films deposited on polyethylene terephthalate on bacterial adhesion. Biomaterials 25:3163-3170.

Wiedbrauk, D. L., J. C. Werner, and A. M. Drevon. 1995. Inhibition of PCR by aqueous and vitreous fluids. J. Clin. Microbiol. 33:2643-2646. 